\title{
PENGENALAN CONTRACTOR SAFETY MANAGEMENT SYSTEM PT PUTRAJAYA SUKSES MAKMUR
}

\author{
Drajat Indrajaya, Endang Suhendar, Asep Endih Nurhidayat \\ Program Studi Teknik Industri, \\ Fakultas Teknik dan Ilmu Komputer, Universitas Indraprasta PGRI \\ Jl. Nangka no.58c, Tanjung Barat, Jagakarsa, Indonesia
}

\begin{abstract}
Abstrak
CSMS atau Contractor Safety Management System merupakan pendokumentasian suatu mekanisme kontrol dalam bentuk panduan untuk menjamin standar usaha dalam pengelolaan kinerja Healthy Safety Environmental (HSE) dari para kontraktor. Sistem ini dipakai oleh pemberi kerja/owner dalam menyeleksi kontraktor, pengawasan pelaksanaan proyek dan mengevaluasi sistem K3 saat proyek telah selesai. Oleh karena itu perlu dilakukan pengenalan dan cara membuat dokumen CSMS pada perusahaan kontraktor sehingga dapat menjaga performa kerja di dunia industri manufaktur khususnya di oil and gas sehingga dapat meningkatkan peluang bisnis di masa yang akan datang. Adapun cara untuk memberikan pengenalan dan cara membuat dokumen CSMS pada perusahaan yaitu berdiskusi dengan pemilik dan karyawan PT Putrajaya Sukses Makmur yang dimana hal tersebut merupakan salah satu tujuan yang akan dicapai didalam kegiatan Pengabdian Masyarakat Program Studi Teknik Industri Universitas Indraprasta PGRI Jakarta.
\end{abstract}

Kata Kunci: CSMS, PKM, industri, dokumen.

\begin{abstract}
The Contractor Safety Management System is a documentation of a control mechanism in the form of guidelines to ensure business standards in managing Healthy Safety Environmental (HSE) performance from contractors. This system is used by the employer / owner in selecting contractors, monitoring project implementation and evaluating the K3 system when the project is completed. Consequently is necessary to introduce and create CSMS documents for contractor companies so that they can maintain work performance in the world of manufacturing industries, especially in oil and gas so that they can increase business opportunities in the future. The way to provide an introduction and how to create a CSMS document on a company is to discuss with the owners and employees of PT Putrajaya Sukses Makmur, which is one of the goals to be achieved in the Community Service Program (Pengabdian Kepada Masyarakat) of the Industrial Engineering Study Program at Indraprasta University PGRI Jakarta.
\end{abstract}

Keywords: CSMS. PKM, industry, document

Correspondence author: Drajat Indrajaya, drajat.indrajaya1@unindra.ac.idCity, and Country 


\section{PENDAHULUAN}

PT. Putrajaya Sukses Makmur merupakan salah satu pemain didalam main power supply, trading dan fabrication didalam industri minyak bumi dan gas (migas) di Indonesia dalam skala kecil menengah. Saat ini perusahaan bermaksud untuk menambah pangsa pasarnya ke dalam perusahaan migas nasional dan internasional yang telah menerapkan sistem CSMS. CSMS atau Contractor Safety Management System merupakan pendokumentasian suatu mekanisme kontrol dalam bentuk panduan untuk menjamin standar usaha dalam pengelolaan kinerja HSE dari para kontraktor. Salah satu permasalah yang dihadapi perusahaan dalam menerapkan CSMS adalah belum adanya struktur organisasi yang tetap dikarenakan struktur organisasi dibuat hanya berdasarkan kebutuhan pekerjaan hal tersebut mengakibatkan perusahaan sulit untuk membuat CSMS yang telah menjadi persyaratan utama jika ingin menjadi kontraktor utama pada perusahaan migas di Indonesia. Contractor Safety Management System (CSMS) adalah Sistem Manajemen Kesehatan dan Keselamatan Kerja (SMK3) yang secara khusus dibuat oleh perusahaan tertentu untuk mengelola Kesehatan dan Keselamatan Kerja (K3) kontraktor-kontraktornya. Davies (2008:2) mendefinisikan 'implementasi' sebagai "menempatkan strategi atau sistem dalam operasi" dan 'implementasi yang efektif' sebagai "sesuatu yang telah beroperasi atau digunakan". Manajemen puncak harus meninjau SMK3 organisasinya secara terencana untuk menjamin kesesuaian, kecukupan, dan keefektifannya secara berkelanjutan. Peninjauan ini harus termasuk penilaian kemungkinan-kemungkinan peningkatan dan kebutuhan perubahan SMK3 termasuk kebijakan K3 dan tujuan-tujuan K3 (OSHAS 18001, 2007:13).

\section{METODE PELAKSANAAN}

Kegiatan pengabdian masyarakat ini dimulai dengan mengurus perizinan dan peninjauan daerah mitra yang dilakukan bulan Maret 2019, proses persiapan penerapan abdmas dilakukan pada awal April 2019. Pelaksanaan kegiatan pengabdian masyarakat dilaksanakan sampai bulan Mei 2019. Adapun tempat kegiatan pengabdian masyarakat ini di PT Putrajaya Sukses Makmur, Ruko Pasar Pagi Bintara Blok A35, Bintara, Bekasi Barat.

Tabel 1. Jadwal Kegiatan Pengabdian Masyarakat

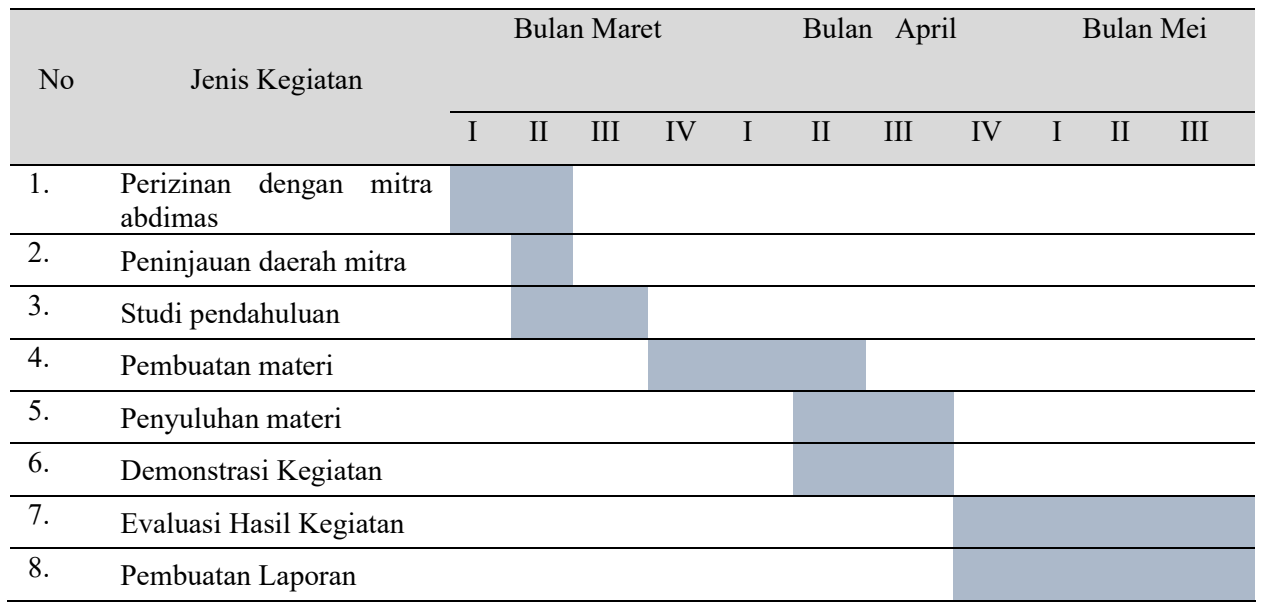



tahap:

Metode kegiatan yang dilakukan dalam kegiatan ini adalah melalui beberapa

1. Observasi langsung. Observasi langsung yakni pengabdian langsung datang ke lokasi pengabdian untuk memperolah data. Hal ini kami lakukan pada saat menjelang maupun saat kegiatan berlangsung. Observasi berguna untuk mengetahui kondisi warga di PT Putrajaya Sukses Makmur Bintara, Bekasi Barat serta menentukan instrumen apa yang diperlukan dalam pengajaran. Observasi sangat penting untuk mewujudkan kesuksesan kegiatan pengabdian masyarakat itu sendiri.

2. Demontrasi, yaitu: tim pengabdian kepada masyarakat melakukan sharing knowledge dan diskusi secara tatap muka langsung kepada pemilik dan karyawan PT Putrajaya Sukses Makmur Bintara, Bekasi Barat.

Adapun peserta kegiatan Pengabdian Kepada Masyarakat ini adalah pemilik dan karyawan PT Putrajaya Sukses Makmur Bintara, Bekasi Barat. Sedangkan pembimbing serta peran sertanya dalam kegiatan Pengabdian Kepada Masyarakat ini adalah sebagai berikut:

Tabel 2. Daftar Pembimbing Pelaksana Kegiatan

\begin{tabular}{lll}
\hline No. & Kegiatan & Pembimbing \\
\hline 1. & Proposal dan Sosialisasi & Drajat Indrajaya M.T \\
\hline 2. & Materi 1 & Drajat Indrajaya M.T \\
\hline 3. & Materi 2 & Endang Suhendar M.T \\
\hline 4. & Pelaksanaan Demonstrasi & Asep Endih M.T \\
\hline 5. & Dokumentasi & Drajat Indrajaya M.T \\
\hline 4. & Evaluasi dan Laporan & Semua Tim \\
\hline
\end{tabular}

Materi pokok yang diberikan pemateri kepada peserta akan dilakukan dengan dua arah, yaitu: pemateri dan peserta terlibat langsung dan aktif dalam suatu bentuk diskusidi dalam kelas sehingga pembelajaran menjadi bermakna. Dengan mengunakan presentasi secara aplikatif dan diskusi diharapkan peserta lebih mudah dan mengerti dalam memahami dalam pembuatan CSMS sehingga dapat segera diaplikasikan oleh perusahaan.

Pemateri harus bisa membuat kegiatan tersebut tidak menjadi membosankan dan materi akan lebih mudah dipahami oleh para peserta sehingga pemateri akan membagi jadwal tim setiap kali pemberian materi kepada peserta di dalam kelas.

Dalam kegiatan Pengabdian Kepada Masyarakat ini juga telah dianggarkan biaya untuk menunjang kegiatan operasional agar kegiatan tersebut dapat berjalan dengan baik. Adapun rincian anggran dana untuk kegiatan tersebut adalah sebagai berikut:

Tabel 3. Anggaran Biaya Kegiatan

\begin{tabular}{cll}
\hline No & \multicolumn{1}{c}{ Jenis } & Jumlah \\
\hline 1 & Biaya Transportasi @ Rp.300.000 sebanyak 3 peneliti & Rp. 900.000 \\
\hline 2 & Biaya Habis Pakai (kertas,tinta dan alat jilid) & Rp. 300.000 \\
\cline { 2 - 3 } & Foto kopi materi (proposal dan laporan ) & Rp. 100.000 \\
\hline 3 & Biaya Komsumsi makan & Rp. 600.000 \\
\cline { 2 - 3 } & Biaya dokumentasi & Rp. 150.000 \\
\cline { 2 - 3 } & Biaya Plakat & Rp. 100.000 \\
\hline 4 & Biaya komsumsi kegiatan 2.350 .000 \\
\hline 5 & Biaya lain-lain & Rp. 1000.000 \\
\hline & Total & Rp.5.500.000,- \\
\hline
\end{tabular}




\section{HASIL DAN PEMBAHASAN}

Pelaksanaan kegiatan ini dilakukan dalam tiga tahap, yaitu: tahap persiapan, pelaksanaan, dan evaluasi. Tahap pertama adalah tahap persiapan. Pada tahap ini, tim melakukan survei pendahuluan dan wawancara awal terhadap pemilik dan karyawan PT Putrajaya Sukses Makmur Bintara, Bekasi Barat, untuk mengetahui target kegiatan, kondisi pemilik dan karyawan yang akan diberikan perlakuan dan menyusun rancangan kegiatan yang akan dilakukan. Tahap persiapan selanjutnya, team menyiapkan bahan bahan yang akan dijadikan pembelajaran sebagai materi pengabdiaan masyarakat ini.

Tahap ke dua yaitu : tahap pelaksanaan. Kegiatan penyuluhan ini dilakukan team dengan memberikan informasi kepada pemilik dan karyawan mengenai penyampaian metode picture dalam menulis paragraf narasi dan penyajian materi yang menarik serta menyenangkan. Tahap pelaksanaan dibagi 3 sesi, yaitu:

Tabel 4. Daftar Kegiatan

\begin{tabular}{clll}
\hline No & \multicolumn{1}{c}{ Materi } & \multicolumn{1}{c}{ Waktu } & Keterangan \\
\hline 1 & Pendahuluan & 1 X 45 Menit & Presentasi \\
\hline 2 & Proposal bisnis & 3 X 45 Menit & Dosen menerapkan Sharing Knowledge \\
\hline 3 & Materi tambahan & 2 X 45 Menit & Diskusi \\
\hline 4 & Evaluasi Akhir & 1 X 45 Menit & Pemberian Evaluasi lisan dan tulis \\
\hline
\end{tabular}

Pengabdian kepada masyarakat merupakan tujuan awal dari kegiatan pengenalan dan pelatihan CSMS kepada perusahaan sehingga dari kegiatan ini masyarakat terutama pemilik dan karyawan PT Putrajaya Sukses Makmur, Bintara, Bekasi Barat akan tahu tentang Unindra dan merasakan pengabdiannya yang memang mereka butuhkan.

Selain hal tersebut diatas, kegiatan PKM ini merupakan salah satu kegiatan yang dapat meningkatkan kesadaran perusahaan terhadap perbaikan sistem manajemen mutu CSMS, sehingga kedepannya bisa lebih meningkatkan dan mengembangkan proses bisnis perusahaan.

Harapan kedepannya adalah Universitas Indraprasta PGRI Jakarta dapat melakukan kerjasama yang berkelanjutan (sustainable) yang saling menguntungkan dengan PT Putrajaya Sukses Makmur dalam rangka penelitian dan abdimas baik yang dilakukan oleh dosen maupun mahasiswa.

Suatu program kerja dapat dikatakan berhasil tentunya mempunyai indikatorindikator sebagai tolak ukur keberhasilan tersebut. Adapun indikator keberhasilan yang dapat diraih didalam kegiatan PKM ini adalah sebagai berikut:

1. Banyaknya peminat yang terdiri dari peserta dan manajemen perusahaan didalam kegiatan PKM ini dikarenakan timbulnya kesadaran dari perusahaan bahwa kegiatan ini sangat diperlukan untuk meningkatkan dan mengembangkan proyeksi bisnis di masa yang akan datang. 


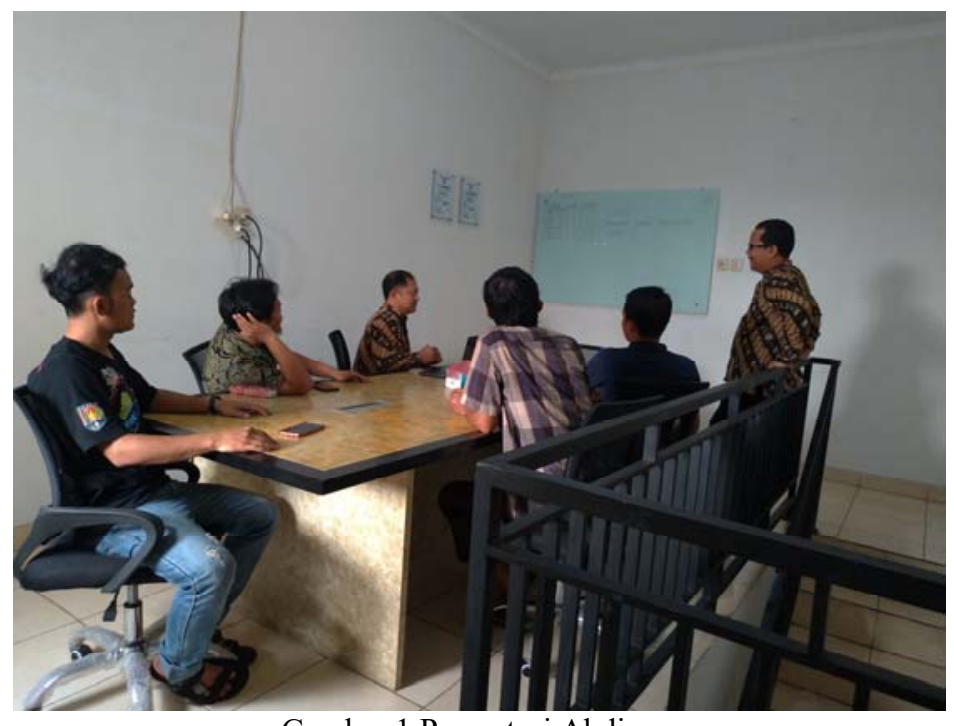

Gambar 1 Presentasi Abdimas

2. PT Putrajaya Suksess Makmur langsung mengaplikasikan hasil kegiatan PKM dengan cara melakukan pendaftaran CSMS ke salah satu Perusahaan Gas di Indonesia melalui portal pis.pgn-solution.co.id.

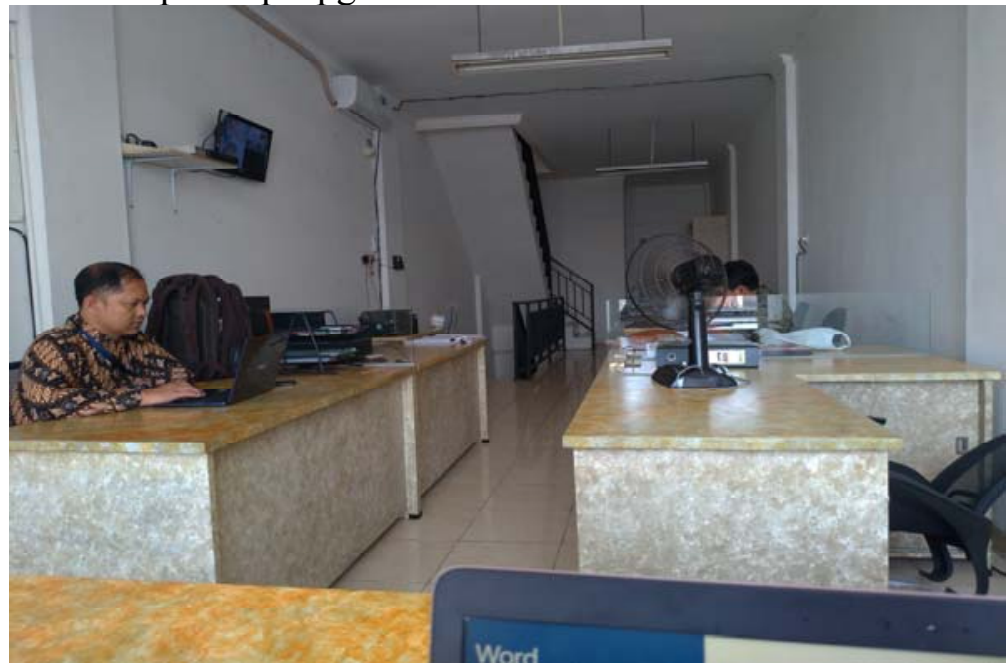

Gambar 2 Kegiatan Membuat CSMS di dalam Portal

3. PT Putrajaya Sukses Makmur menginginkan dilakukan kegiatan PKM yang terkait denga visi dan misi perusahaan secara berkesinambungan yang diselenggarakan oleh Universitas Indraprasta PGRI Jakarta. 


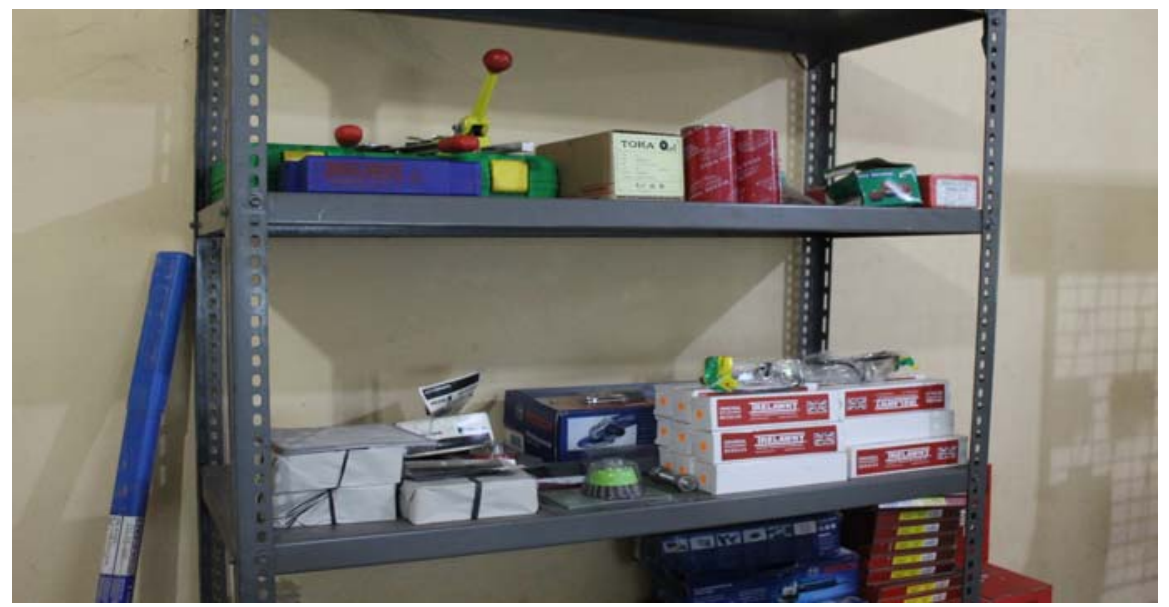

Gambar 3 Produk PT Putrajaya Sukses Makmur

PT Putrajaya Sukses Makmur berkomitment untuk membantu pengembangan research yang dilakukan oleh dosen maupun mahasiswa di lingkungan Program Studi Teknik Industri Universitas Indraprasta PGRI Jakarta.

\section{SIMPULAN}

Kegiatan ini berjalan dengan baik, dan kegiatan ini sebagai awal bagi perusahan untuk mengetahui prinsip CSMS dan bagaimana cara untuk membuat CSMS dengan memperhatikan seluruh ruang lingkup pekerjaan dapat dilaksanakan dengan baik, benar dan aman sesuai dengan prosedur kerja dan ketentuan yang berlaku.

Untuk mengatasi semua kendala yang terjadi pada saat kegiatan pengabdian kepada masyarat ini diperlukan cara sebagai berikut:

1. Pembaharuan sistem CSMS perusahaan wajib dilakukan 1-2 tahun sekali disesuaikan dengan hasil pembaharuan sistem HSSE perusahaan.

2. Kontraktor harus memperbaharui sistem CSMS kontraktor melalui link perusahaan sebagai berikut https://pis.pgn-solution.co.id/ setiap 5 tahun sekali

3. Kegiatan pengabdian kepada masyarakat perlu dilakukan secara terus menerus sehingga perusahaan dapat mengimplementasikan CSMS secara terus menerus.

Perlu dilakukan integrasi antara tema kegiatan pada satu objek penelitian, sehingga perusahaan akan mendapatkan pengetahuan secara menyeluruh dan bisa bermanfaat didalam lingkungan sekitar.

\section{DAFTAR PUSTAKA}

Alberta Province Government OHS - Canada. (2015). Leading Indicators forWorkplace Health and Safety: a User Guide.

Amir, M. (2012). Manajemen Strategik: Konsep dan Aplikasi. Jakarta: RajawaliPers.

Davies, J. (2008). Integration: is it the key to effective implementation of theEFQM Excellence Model? International Journal of Quality \& ReliabilityManagement, Vol. 25 Iss: 4, pp.383 - 399. 
Keputusan Menteri Pertambangan dan Energi No.555 Tahun 1995. (n.d.).tentang Keselamatan dan Kesehatan Kerja Pertambangan Umum. 1995. Jakarta: Departemen Pertambangan dan Energi Republik Indonesia.

OSHAS-18001. (2007). Occupational Health and Safety Management Systems Requirements. London.

Peraturan Menteri Energi dan Sumber Daya Mineral No. 38 Tahun 2014. (2014). Penerapan Sistem Manajemen Keselamatan Pertambangan Mineral dan Batubara. Jakarta: Departemen Energi dan Sumber Daya Mineral Republik Indonesia.

Peraturan Menteri Tenaga Kerja No. PER.5/MEN/1996. (1996). Sistem Manajemen Keselamatan dan Kesehatan Kerja. Jakarta: Departemen Tenaga Kerja Republik Indonesia. 